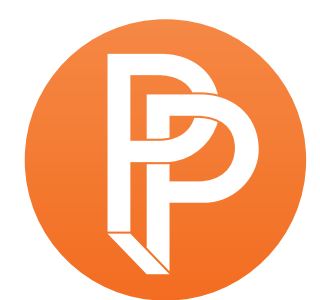

PERFORMANCE

PHILOSOPHY

\title{
ETHOS FORMULA: LITURGY AND RHETORICS IN THE WORK OF TED SHAWN
}

\author{
ALEXANDER SCHWAN FREIE UNIVERSITA'AT BERLIN
}

Ethics and aesthetics are one.

Wittgenstein (1922), 6.421

\section{Choreoethics}

Giorgio Agamben begins his seminal chapter "Ethics," in The Coming Community, with a bold claim. Almost in the form of an aperçu he demands for "any discourse on ethics" to start with the allegedly indispensable fact "that there is no essence, no historical or spiritual vocation, no biological destiny that humans must enact or realize" (Agamben 1993, 43). Drawing a traditional distinction between ethics and morality-individual ethical reflection on the one hand, and adherence to an heteronomous moral law on the other-Agamben links ethics to a radically increased potentiality. Ethics does not provoke or guide moral decisions, but nor does it derive from them as secondary reflection. It is rather the fact that human beings are consigned to an array of possible decisions, which brings ethics into play. Making any decision involuntarily spurns the majority of these possibilities, and so potentiality always meets with experiences of lacking and missing, of being and feeling guilty without having committed "any blameworthy act" (Agamben 1993, 44). Agamben here admits that this potentiality very much resembles the Biblical understanding of sin as an anthropological constitution rather than a moral default or misdemeanour. Ethics doesn't have a foundation but is fundamentally linked to potentiality through the experience of lack, of doing something by not-doing something else and of making one decision by deciding against any other possible option. 
Agamben's alignment of ethics to potentiality also lends itself to dance. For dancers are well acquainted with the experience of making one decision against the entire field of possibilities. Simply by moving, by making a step, taking a leap, or turning and twisting the body, they elect this particular movement over all other possible ones. And by executing this choice, they deliver themselves to a new field of potentiality opened up by this single moment of dance. Thus moving the body in space doesn't follow a mere heteronomous law, and if it attempts to do so, it nevertheless deviates from this law in every single inexactitude, every shaking, trembling, and dismissing of a prescribed figuration. Dance studies, often in direct reference to Giorgio Agamben's or Gilles Deleuze's philosophical thinking, has drawn upon this close relation between movement and potentiality, arguing for dance as an eminently potentiality-bound art form (Gil 2006; Manning 2009, 15-28).

Yet, what dance studies has not yet explored in full is the integration of ethical concerns into dance's alignment to potentiality. Does the openness of dance, its refraining from executing a mere prescription, evoke any kind of responsibility? And how does ethics apply to forms of dance which-unlike those strands of postmodern or contemporary dance that choose to use improvisation or highlight the individuality of dancers-value the heteronomy of a choreographic law or traditional movement codification?

By refusing any foundation of ethics including "historical or spiritual vocation," Agamben places himself in relation to a traditional Christian discourse of antinomianism (see Liska 2008, 47-67). Rooted in a one-sided reading of Pauline theology that diminished Paul's appreciation of the Torah, the antinomistic tradition emphasized his criticisms of vó also includes the universal law or the general law of nature (see Taubes 1993, 37). While Agamben seems to follow this antinomistic tradition in his questioning of a historical vocation of ethics, he simultaneously opposes an account of the Christian tradition as overcoming the influence of an external law through turning to an inner or spiritual law. But Agamben also approaches the tradition of antinomianism dialectically: Much as he wants to abolish any heteronomous foundations of ethics he also emphasises the fact that Paul's criticisms of the law do not cancel out his appreciation of the Torah. This Hegelian understanding of Paul's relation to the law is made explicit in his recent publication The Use of Bodies, where he uses the German verb aufheben as meaning both "abolish" and "preserve" (Agamben 2016, 273).

This dialectical understanding of the non-foundation of ethics in pure potentiality also bears consequences for dance and the question of how bodily movement can relate to the law. Following, or at least paralleling, Agamben in his discussions of law and heteronomy, in particular, dance theorist André Lepecki emphasizes the anarchic aspects of dance. According to Lepecki dance's presence shall ultimately be nothing less than "undecidable, multiple, lawless, a presence whose present can point simultaneously toward yet unthinkable ontological coimpossibilities of pastness, presentness, and futurity" (Lepecki 2004, 137). Lepecki ultimately argues that dancing, particularly in its contemporary forms, can-and even shall-separate itself from any prescriptions of the law, whether this might be in the shape of the instructions of a choreographer, the demands of a score 
or the embodied traditions of movement codifications and normalisation in general. By contrast, Gerald Siegmund echoes Agamben's more dialectical approach when he writes:

\section{The body with its infinite possibilities of moving, which are always already the result of both cultural and dance techniques, touches the law that in the act of connecting also produces this very dancing body. In the absence between the body and its manifold possibilities of moving and choreography, a negotiation of the relation between body and law takes place. (Siegmund 2012, 212)}

Taking another angle, the French psychoanalyst and philosopher Daniel Sibony, who has studied with Emmanuel Lévinas and was educated in the system of Jacques Lacan, also focuses on the idea of the dancing body as always already related to a law, yet a law in the status of scarcity lacking its presence and final fulfilment. This lacking law nevertheless governs the moving body, since the body wants to free itself precisely from its absence: "Il faut comprendre qu'il s'agit souvent de se libérer d'un manque de loi, de reprendre contact avec la loi qui est à l'œuvre-pour qu'elle décharge le corps d'un poids qu'il n'a pas à porter" (It is important to understand that, in most cases, we have to free ourselves from a lack of law and have to reconnect with the law that is at work, so that it may discharge the body of a weight the body cannot carry) (Sibony 1995, 117). Needless to say, this positioning of dance and law also leads to different perspectives on the ethical implications of dance: While Lepecki's and Siegmund's positions on dance's relationship to the law tend to address the politics, rather than the ethics of dance, Sibony's approach allows for reflections on the ethical responsibility of dance in conjunction with an appreciation of the responsivity of the moving body. Dance, and particularly contemporary dance, in Sibony's account, does not only claim a position of otherness insofar as it might circumvent the law and possibly escape the heteronomous determination of the body, but also in terms of the alterity of dancer and spectator, and the alterity of the unconscious-both the dancer's and the spectator's (Sibony 1995, 123-27).

Are dancers responsible for their movement, when do they move ethically, and can dancing itself be a guilty act? Agamben's ethics of potentiality and ontological lack answers such questions only in parts. It is Sibony's emphasis on the heteronomous character of law as a transcendental condition of dancing which offers richer possibilities for opening up an entire field of relationships between dancing and ethics. Sibony's Lacanian understanding of la Loi does not identify the law with mere rules or prescriptions or with basic physical laws such as the law of gravity (see Schwan 2011, 116-17). He rather regards law as a general and indispensable background to the human body, a condition or nexus, from which any movement derives-in particular the movements of dancing. These movements, more than other purposeful movement, are deeply affected by the fact that the general law is always in the status of being too weak, too absent and too ineffective. Law in such an extended interpretation cannot and must not be restricted to specific normalizing rules or standardizing factors. To reduce the nexus of law and movement solely to the constraints and restrictions that seek to govern and oppress the body (see Legendre 1978, 73-81) would be a simplification that loses the potential for dialectic, seeking liberation, like antinomianism, from a distorted picture of the law. However understanding law as a complex nexus of factors and 
processes that structure and influence the moving body-a nexus that includes heteronomous aspects but exceeds them-allows for a more subtle and rich understanding of how ethics and gesture might be related.

History and tradition have loaded certain movements, poses and gestures with cultural meanings, which-albeit arbitrary and dependent on context-are to some extent consistent in their codification. Such repeatable and recognizable movement patterns also belong to the nexus of heteronomous influences on the human body and are thus part of the law with which dancing is unavoidably connected. This applies in particular to the interweaving of movement patterns with emotions, which might bring Aby Warburg's theory of pathos formula into play (Warburg 2010). Warburg used this configuration to analyse the Western artistic tradition of representing emotional or affective content-like fear or anger-in specific poses through showing how pathos-driven movements affect, say, the falling of hair or the drapery of a billowing robe.

Beyond the narrow field of emotion, these movement formulae, as part of the nomistic nexus that facilitates and structures bodily movement, must be readable as gesture. For here, in the realm of intentional and communication-oriented gesturing-greeting, welcoming, or refusing-the formula- and sign-like character of movement demands the deciphering of encoded content. Through this process of decipherment, gesturing becomes part of a rhetorical system. It is worthwhile asking to what extent this rhetorical understanding of movement applies to dancing, and especially to those forms that visibly follow modes of codification or locate themselves within textual understandings of movement, of writing and reading dancing (see Brandstetter 2015, 2529).

The readability of these movement formulae partakes of the structuring process of a law that is always already behind or-as Sibony would rather put it (Sibony 1995, 41-53) -in front of the dancing body. This opens an entire nexus of ethical dimensions, which can be termed, after Aby Warburg's pathos formula, ethos formula (see also Brandstetter 2013, 521). The idea of ethos formula refers, in a way that is equivalent to the pictorial tradition of a pathos formula, to the encoded movement patterns of ethical attitudes or comportments that are motivated by decision-making rather than emotional content. Gestures and their citation in dance might bear an ethical dimension similar to the encoded transmission of emotions through movement in a pictorial tradition.

Gestures that signify greeting, welcoming, help-offering, neglecting, refusing, or oppressing, are by no means universal, but rather culturally encoded, and as such, they transport ethical content. This idea of ethos formula stands in stark contrast to Agamben's attempt to locate-or, better, dislocate-ethics, but it does not distort ethical decision-making to a mere following of moralistic imperatives. Ethos formulae are heteronomous, because their encoding of gestures is already part of an existing, supra-individual network of structuring ideas. But this does not imply absolution from responsibility or culpability. On the contrary, conceptualizing, executing and reading a gesture as an encoded ethos formula requires decisions to be made according to an individual understanding of context in an always newly established congruence with ethical principles like justice, proportionality, and reciprocity. 


\section{Modernist Dancing}

Reflecting on the ethical impact of bodily movements in the context of art and performance affects the many-faceted relationship between ethics and aesthetics and between dance and religion. With the autonomization of the arts in modernity, dance allegedly shifted towards an oppositional relationship to religion. Whereas dance in antiquity and the Middle Ages was a core expression of virtue and was, in an albeit limited way, charged with morality-for example in the Neo-Platonic parallelisation of the spheric harmonies of stars with the circular movements of human dancers (Miller 1986) - the different waves of modernity gradually questioned those equations of bodily virtuosity and moral virtuousness. The last of those waves, the rise of modernism around 1900, seemed to destroy the idea of an ontological equation between beauty and virtue to such a degree that it now seems far-fetched, if not erroneous, to ask for morally correct dancing. Finally, the modernist withdrawal from classical ballet and from its strict movement codification gave birth to the anti-nomistic fascination with lawlessness, presence and the ideal of self-expression that is still palpable in dance theories today (Lepecki, Siegmund).

A closer look at dance's modernist aesthetics, however, reveals a strikingly different picture. In this picture, high-modernism is characterized by a profound ambiguity, where dancers and choreographers seek authenticity in bodily expression, yet still cling to older ideas of taxonomizing and codifying movements-even if not in the form of classical ballet. This attempt to overcome the alienation of modernity by reaching back to older, allegedly purer and less corrupt forms of living and dancing (for instance in Greek antiquity) pursues an anti-modern discourse within modernity itself. Much like the protagonists of other liberation movements of the time, the lead figures of early modernist dance remained in ambivalent relation to the avant-garde-both claiming a departure into the new and unfamiliar, and simultaneously longing for older essentialist ideas of life and art.

Modernist dance, however, also had to cope with the particular burden of long-standing restrictions and disallowances at the hands of Christianity. While Judaism had maintained a more positive attitude towards dancing that goes back to the psalms and stories of the Bible, Christianity developed a clearly pejorative and even punitive attitude towards dance, implementing prohibitions and preaching through sermons against dance. This gave rise to a deep social and discursive gap between the realm of dance on the one hand and church and religion on the other. As part of the Constantinian shift and the rise of Christianity to political power, there was a wide adoption of the Stoic criticisms of dance prevalent in late antiquity (see Andresen 1961), and this led to an almost complete exclusion of dancing from church services-with some remarkable and peculiar exceptions like the Shakers' dance (Wagner 1997, 178-80).

In harsh contrast to the tribute early Christianity could pay to dancing when it came to wellregulated bodily movements paralleling the movements of the stars, the later Church demonized dancing, as encouraging lust or immorality (see Wagner 1997). The impact of this equation is of course immense when it comes to the question of ethics in dance. For against the background of a century-long denial of moral status, modernist dancing not only had to break free from religious 
repression, but also from the denial of its moral value and from the exclusion of its positive ethical reflection. Modernist dance thus had to deal with a clear double-bind: As part of the aesthetic autonomization of the arts, dance separated itself from religious or moral dominance, whilst simultaneously reclaiming the high moral status it had been denied by the Church for centuries. To counter this moral disbarring and to gain full entrance into ethical responsibility, modernist dance did nothing less than become religious in itself, promising its disciples a better life through dance (see LaMothe 2006).

Many protagonists of modernist dance, such as Ruth St. Denis, Ted Shawn, Isadora Duncan, Mary Wigman, Charlotte Bara and Martha Graham, understood dance movement in extremely religious terms (see Zander 2001). While escaping from the narrow boundaries of institutionalized religion on the one hand, they also developed a new religion of dance on the other. And most interestingly, the religious upbringing of the protagonists of early modernist dance often influenced their ideas about dance, such that theologoumena of their confessional backgrounds correspond to facets of their dance philosophy. While Mary Wigman's Lutheran background agreed with the submissive and mystical aspects of her dancing and her emphasis on topics like death, sacrifice and suffering (see Schwan 2009), Martha Graham's understanding of dance had a decisively Presbyterian character. She could trace her American family history back to Myles Standish-one of the Pilgrim Fathers who arrived with the Mayflower in Massachusetts in 1620-and a Puritan background was still clearly visible in Graham's strict attitude towards training and in the discipline and execution of movement. Graham even transferred the distinctive Presbyterian doctrine of election to the realm of dancing, convinced that certain people were chosen to be dancers and should therefore behave and move according to this elect status (see Graham 1991, 5). Charlotte Bara, who converted to Catholicism at the age of 27, focused her expressionist dancing on topics such as purity, piety, and the Arcanum, where protagonists of modernist dance in Israel like Baruch Agadati and Gertrud Kraus gave their dancing a distinctly Jewish character with numerous references to texts form the Hebrew Bible (see Manor 1986; 1988).

\section{Ted Shawn}

Ted Shawn (1891-1972), the "Father of American Dance" (Terry 1976), conceptualized dance with strong theological implications. He had briefly studied Methodist theology before becoming a dancer and choreographer and this theological background remained legible in his dance works. Many of these works transferred religious texts, topics and tropes into dancing, sometimes with biblical figures as core references for the choreography. One could think of Shawn's impersonation of Joseph in his piece Joseph's Legend (1915) or, most notably, his involvement with the figure of Jacob, who even became eponymous for Jacob's Pillow, his training centre for exclusively male dancers in Becket, Massachusetts.

Ted Shawn did not only develop dances inspired by Biblical texts and choreograph entire series of dance pieces dedicated to a wider spectrum of religion or spirituality (though these nonetheless still followed Protestant presuppositions), he also wrote and published extensively on the relationship between dance and religion. Whether echoing Nietzsche's dictum “I would only believe 
in a god who knew how to dance" (Nietzsche 2006, 29) in the title of his book Gods Who Dance (Shawn 1929), or writing of religion in The American Ballet (Shawn 1926) and Dance We Must (Shawn 1974), Shawn proclaimed dance as a legitimate form of religious expression. He sometimes combined this proclamation with a confessional autobiographical reference to his early career as a student of Methodist theology and his conversion experience of turning to dance. This again reveals a typically Protestant attitude of authenticating an argument through individual experience:

\begin{abstract}
Studying to be a Methodist minister, I was interrupted in my junior year at University by a severe illness, which kept me in bed quite motionless for many weeks. During this enforced quiet I had time to think deeply, and I thought myself out of the ministry, out of the Methodist church, and free from all previous moorings. And when I finally crystallized, within my consciousness, and came out with a form, it was the form of the dance as religious expression. Of course, all of my friends thought that I was headed straight for the south gate of Hell. It was not really a change of base at all, it was only a change of form [...]. I, pursuing religion [...] found the dance was the first and finest means of religious expression. (Shawn 1926, 12)
\end{abstract}

Shawn referred to the idea of dance as a primordial form of religious expression extensively in his books, lectures and public presentations. Yet, in some respects his use of terms like spiritual, ritual, sacred, myths and mysticism remained remarkably unclear and imprecise. How did they differ from one another, not to mention from the sphere of the profane, the contemporary, and modern everyday-life? This imprecision was linked to another more serious problem when it came to interreligious or transreligious references. For Shawn used adjectives like religious, spiritual, or sacred not only in relation to the phenomena of his own Christian background, but also emphatically in his approaches to non-Christian religions and beliefs. Here, he worked with the impossible assumption of universality, which in itself betrayed the heritage of Christian claims to superiority. Much like his wife and dance partner Ruth St. Denis, Shawn exoticized expressions of non-Christian spirituality and, as part of a "cultural imperialism" (Desmond 2011, 256), colonized them in his project of a religiously-charged modernist dance aesthetic.

As a white American Protestant, Shawn constructed religious otherness in his dances by declaring movement in non-Christian contexts as spiritual while at the same time using a Christian vocabulary that was not sensitive to the specific understandings of religious movements within those non-Christian contexts (say, Hinduism or Buddhism). Shawn mimicked this distorted understanding (or misunderstanding) of religious dancing in his choreographic work in the name of spirituality or sacredness. But this was always effected within a declaredly nationalist sentiment that came along with an apparently racist position of white supremacy (see Scolieri 2016, 196). Arguing from this point of view in his book The American Ballet (Shawn 1926), Shawn characterized "the influence of black dance on American social dance as a degenerated one" (Burt 1995, 109) and in Dance We Must (1940) he even complained about this influence in an openly racist way:

I was sick at heart that we, this whole vast country of millions of white people, still kept on dancing dances of negro derivation. Have we lost completely the qualities that made us a great nation? We were capable in the past of creating our own 
Despite this position, and the fact that he had no dancers of a Black-American or Native American background, he developed religious themed choreographies, like Negro Spirituals or Xochitl, that colonized non-white dance and music traditions from the North- and Middle-American continent. While in Xochitl, Shawn clearly exoticized Indian American culture in a stereotypical use of feathers, weapons, leather-skirts and naked skin, the case of Negro Spirituals is different. Here, Shawn completely neglected the specific black context of the spiritual tradition and performed instead "generalized moods of lamentation and lament" (Manning 2004, 10) by declaring his own modernist dance movements as expressions of allegedly universal spiritual experiences.

The ideology of Ted Shawn's and Ruth St. Denis's white Christian supremacy in dance also included arguments and practices of Anti-Semitism. According to Doris Humphrey's biography, St. Denis limited the number of Jewish students in the Greater Denishawn school to ten percent (see Humphrey 1995, 62). One might expect a similarly Anti-Jewish discourse in Ted Shawn's conception of dance as a means of religious expression. But Shawn's own dance theology seems to be free from any explicit Anti-Judaism and, in contrast to Ruth St. Denis (see LaMothe 1998) he never argued with Christological theologoumena that would exclude a Jewish or non-Christian approach to dance. Rather than referring to Jesus Christ as the Lord of the Dance-a typically Christian way of justifying dancing-Shawn saw dance as a primordial form of religious expression which had been lost in the process of Western civilization and which, according to a primitivist argument, had mainly survived in non-Western cultures. This was waiting to be revived in Western culture by Shawn and other choreographers who brought dance and religion back into dialogue.

This idea clearly rested upon the biblical scheme of a paradisiacal state of nature-its decay and redemption-and Shawn's affinity for this scheme was shared by many other protagonists of early modernist dance and of Ausdruckstanz or expressionist dance in particular. With the rootedness of Ausdruckstanz in the philosophy of life (Lebensphilosophie) of the $19^{\text {th }}$ century, and in its ideals of movement, nature and organic becoming, early modernist dance worked with this tripartite salvation-oriented scheme. Industrialization, urbanization and, paradoxically, modernity itself signified a metahistorical decline from an allegedly pure past that was then necessarily followed by its amelioration and (self)redemption. In this line, Isadora Duncan claimed that "dance was once the most noble of all arts-and it shall be again. From the great depth to which it has fallen it shall be raised" (Duncan 1903, 15).

\section{Liturgical Gestures}

Ted Shawn proclaimed a pronouncedly religious understanding of what dancing is and how dancers should move, strike a pose or make a gesture. And it comes as no surprise that these dance moves often emulated gestures from a religious context like private worship, ecstasy, andquite frequently and very symptomatically for Shawn's aesthetics-situations in which an individual is confronted with an overwhelming divine power and reacts to these experiences of the 
sublime with submission and devotion. To depict these situations, Shawn tended to position the body sitting or even laying on the ground, often with uplifted hands and the torso bowed backwards as if in self-abandonment to the experience of being overpowered by an invisible divine entity. As movement formulae of spiritual experience, Shawn quoted these poses and gestures from the history of Christian religious art and interpreted them in his own modernist aesthetics. Rather than dealing with movements of uncontrollability, fragility and weakness-also part of the vocabulary of spiritual movement formulae in the history of Christian art-Shawn radically emphasized aspects of strength, expansiveness and bodily erectness. Thus combining religiousness with athleticism and spirituality with homoerotic virility, Shawn's male-centred body aesthetics referred back to Muscular Christianity, a philosophical movement that originated in England in the mid-19 $9^{\text {th }}$ century and became popular in North America in its propagation of moral and physical beauty (see Burt 1995, 108; and also Foster 2001, 160-69).

A similarly citational and elevating appropriation of pre-existing religious gestures can be seen in the way Shawn invoked the realm of public worship. His choreographies re-incorporated either gestures performed by members of a congregation, like kneeling, bowing, turning-or, and with a remarkable emphasis-gestures that in a service would normally be carried out by the figure leading the service as $\lambda \varepsilon$ cเoupyóc (leitourgós, officiant). It is here, in the quotation of these liturgical gestures-or ethos formulae-of greeting, welcoming, and directing the members of a congregation, that Shawn's dance aesthetics displays its most pronounced overture towards an ethics of gesture.

These liturgical gestures are variously relational-they can relate the officiant both towards the presence of the congregation or public (coram publico) as what directs and conducts, and towards a divine entity (coram deo). Depending on the specific understanding of liturgy in the different religions and denominations, these two basic alignments of liturgical gestures can be either indistinguishably interwoven or held in separation. The complexity of religious divergences in these questions becomes still more intricate in light of other possible alignments of liturgical gesture. For instance, they can also be directed towards oneself (coram meipso) or towards the entire world outside the congregation (coram mundo, coram hominibus) to cite just one example of a Christian, distinctly Lutheran Protestant, conception of the various possible alignments of liturgical gestures (see Kabel 2002, 38-55).

In 1915, Ted Shawn developed a short choreography based on Psalm 23, which "was to be one of three Dances of David (The Boy, The Shepherd, The King)" (Shawn 1979, 70). Shawn would return to the Twenty-Third Psalm continuously over the following decades and considered this biblicalthemed dance piece so important that he put it at the beginning of the opening ceremony for his new dance studio in Los Angeles in April 1920. But most importantly, he integrated the TwentyThird Psalm into his Dance Church Service, which had its premiere in the First Interdenominational Church in San Francisco in 1917 and later became part of a programme with which Shawn toured the U.S.-holding performances on major stages like the Carnegie Hall or the Metropolitan Opera in New York. The Dance Church Service represented a Protestant church service in rhythmic movement. It transformed liturgical pieces like Opening Prayer, Doxology, Gloria, and a Psalm into 
dancing, and centred around a danced sermon on John 8:32 "Ye shall know the truth and the truth shall make you free", danced by Shawn himself, after Martha Graham had danced an Andante Religioso.

This cornerstone of his early choreographic work was subsumed, by Shawn, under his tripartite salvation-oriented scheme for the primordial connection of dance and religion. This scheme wasn't proposed as an intervention against the U.S. religious establishment, but rather as a legitimate innovation that any Protestant church might accept with open arms. He recounts its largely positive reception:
I [...] did this dance church service in some thirty or forty cities and only once was serious opposition shown, when two hundred preachers and laymen threatened to tar and feather me in Shreveport, but the entire police force protected me by saying that these fanatics would be treated like any other lawbreakers. When the service was over, the mayor and aldermen came and congratulated me and gave me letters on their official stationery attesting that the service was reverent, and that they recommended it to other cities; while over and over again in other cities, ministers would come to me after my dance service and tell me how they felt its rightness how they wished they could introduce it into their churches. (Shawn 1974, 31-32)

In the same publication, Shawn admitted that his Dance Church Service wasn't the very first intermingling of a Christian service with early modernist dance. The Episcopelian clergyman William Norman Guthrie, during his time as rector of St. Mark's Church in-the-Bowery, New York, had also created services and liturgies that incorporated the arts, literature, and various religious traditions. Contemporaneous to Shawn's Dance Church Service, but independently from it, Guthrie initiated a Ritual Dance of the Della Robbia Annunciation in which the dancers' poses referenced a replica, hanging behind them on the Church wall, of Andrea Della Robbia's famous fifteenthcentury terracotta. As in Ted Shawn's work, later choreographic interventions in St. Mark's Church in-the-Bowery also made way for prominent protagonists of early modernist dance like Isadora Duncan and Martha Graham, who helped to turn this particular Church into a hub for the modernist entanglement of dance and religion (see Wenger 2006).

Pictures of the Ritual Dance of the Della Robbia Annunciation showing the dancers in situ of St. Mark's Church in-the-Bowery have survived. Interestingly, in mimicking and interpreting religiously themed body positions from Andrea Della Robbia's fifteenth-century terracotta through modernist dancing, the gestures of the dancers also resemble those poses that Ted Shawn had presumably shown in his own works. Unlike the Ritual Dance of the Della Robbia Annunciation, however, the actual performances of Shawn's Dance Church Service and the Twenty-Third Psalm were not photographed. The surviving paraphernalia in the Harvard Theatre Collection at the Houghton Library and the New York Public Library mainly consists in programmes and studio photography showing Shawn in costume striking key poses. Dressed in flowing white cloths with his head wrapped in an orientalising turban, Shawn illustrated the Biblical text not only with poses of standing, kneeling, and lying, but also with liturgical gestures of greeting and blessing. Most 
peculiarly, Shawn even preferred the outdoor surrounding of a Californian landscape as a setting for the Twenty-Third Psalm, which Edward Weston (1886-1958) photographed in the real locations of a meadow and a pond, as a reflection of the line in Psalm 23: "He maketh me to lie down in green pastures: he leadeth me beside the still waters."

Presenting Shawn in orientalising costumes and lasciviously posing in a Californian landscapesetting, Edward Weston's pictures of the Twenty-Third Psalm are stellar examples of a Proto-Camp aesthetics that approaches the pictorial traditions of Christian art from a modernist perspective by giving it a homoerotic twist. Shawn even added further layers of such queer appropriation, when he used one of Weston's pictures for a Christmas card in 1915. Yet, this peculiar fact reinforces the question, who is Shawn impersonating in his version of Psalm 23? Is he embodying Jesus Christ as the Good Shepherd, referring to a Christian tradition of reading the Psalm as a prefigurative notion of Christ? Or is he, rather, depicting a member of the flock, protected by the shepherd God? These questions are crucial to the character of the liturgical gestures that Shawn quotes and re-enacts: Is he, in impersonating the Good Shepherd, an officiant or priest who not only administers a blessing, but rather donates and bestows it? Or is he receiving a blessing himself? It seems appropriate to argue for the latter reading inasmuch as "Three Dances of David" suggests that Shawn means to personify David, the alleged author of the Psalm who expresses his experiences with God through the metaphor of sheep and shepherd.

The question also arises as to how far Shawn's gesture material from the outdoor pictures of the Twenty-Third Psalm resemble his body movements in the actual choreography onstage. This problem also applies to the studio photography of the Dance Church Service and most prominently to the sermon, as the centre-piece of the choreography. Yet, even accepting that the pictures would have stressed the more durable poses rather than Shawn's dynamic movements, it seems fair to assume a visual similarity between his posing at the bank of a pond in California and his dancing on stage. Since he declared outdoor- and studio-photography as related to his stage performance, it seems fair to suggest that at some points of the choreography, most probably at its climax, Shawn actually struck the poses and made the gestures captured in the photographs. Standing upright and having his hands folded in front of his solar plexus, he opened his arms slowly and symmetrically, raising them to a point where his fingers still pointed to the ground and his open palms reached towards the audience in a gesture of devotion, greeting and blessing.

The liturgical character of this gesture still resonated with Shawn's Methodist background, since he primarily positioned arms and palms as if virtually receiving or gathering a divine blessing, rather than donating or radiating it. While the latter would have been the case in a Catholic or Lutheran approach, Shawn's gestures by contrast maintained the theonomous character of blessing. For in a Reformed Protestant tradition, God himself is the only source from which all blessing flows, whereas the liturgical gesture of a human officiant can, at most, only solicit this divine blessing. This gesture thus ultimately integrates the $\lambda \varepsilon$ cıoupyó (officiant) into the community-the people leading a service are not inherently different from the people attending the service, they are pares inter parem, and only represent a sacred or divine other. Their liturgical gestures have a much more rhetorical or citational character. Rather than performing a holy act or opening up a sacred sphere, 
these gestures are predominantly this-wordly, deriving as they do from the realm of politics and rhetoric. In this sense, they are ethos formulae: conventionalised gestural patterns that indicate ethical relationality, rather than metaphysical superiority.

This, again, draws on Shawn's Methodist background in its understanding of ethics. For the Methodist movement, which began in the mid-18th century as a reform movement within the Church of England, forms part of the Arminian tradition of Christianity. It denies the idea of a double predestination, in which God had pre-ordained a handful of the elect to eternal bliss while others were doomed to perish eternally. By contrast, the Arminian tradition and with it the Methodist movement and church asserted that people are all by nature dead in sin, are justified by faith alone and not by merits. This status of faith results in an ethical lifestyle and is thus testified by a visible involvement in charity, social activities, and politics. One might interpret Shawn's pedagogical ambitions, his lecturing and teaching, and even his participation in missionary practices, as part of this involvement in Methodist ethics. Here, too, Shawn was a product of his Protestant background, but his interest in dancing in non-Christian religions interfered quite problematically with his support for religious missions, as when, for instance, he presented his dances at fundraising events supporting Christian missions to China.

\section{Rhetorical Gestures}

Shawn's liturgical gestures not only embodied the specific ethical aspects of Reform Protestantism, such as sanctification, self-enhancement and socio-political commitment, in all of their ambivalence. There is another, highly complex spectrum of references within these liturgicalrhetorical gestures: the Delsarte system, created by $19^{\text {th }}$ century French musician and teacher François Delsarte. Very popular both in Europe and in North America at the end of the 19th century, Delsarte's system was used to analyse, codify, prescribe and ultimately train certain movements, especially in the context of public speaking, acting, pantomiming or dancing (see Ruyter 1999, Preston 2011, 59-99). Shawn himself wrote a book on the system called Every Little Movement. A Book about François Delsarte, The Man and His Philosophy, His Science of Applied Aesthetics, The Application of This Science the Art of the Dance, The Influence of Delsarte on American Dance (Shawn, 1963). This book, first published in 1910, remains one of the most comprehensive summaries of the Delsarte system, and there is no doubt that this system served as a key source of inspiration for Shawn's choreographic work, especially during his early years.

Not unsurprisingly, this system carries inherently religious undertones-it is based, after all, on varying structures of intermingling trinities. François Delsarte, coming from a decidedly Catholic background, follows the main premise that transcendence is mirrored in the materiality of bodies, and that depending on the bodily part from which a movement originates and where it points to, a certain fixed meaning or emotion can be expressed through codified gestures. In codifying these gestures, and in following this codification, specific expressions may be transmitted from the performer of the gesture to the spectator. Rather than a strict nomistic system, capturing the body and prescribing "every little movement," it allows for the idea of communication-in what is almost 
a $19^{\text {th }}$ century anticipation of the model of kinaesthetic correspondences between stageperformers and audience.

One cannot overestimate the importance of the Delsarte system, not only for Shawn, but for most of the lead figures of early modernist dance, and of Ausdruckstanz in particular (see Jeschke/Vetterman 1992; Wedemeyer-Kolwe 2012). Explicitly or unconsciously they followed the main idea that expression is not an internal, spontaneous feeling that is expressed in improvised movement but rather a communication of codified and pre-existing movement materials. From a contemporary perspective, this codification was more likely arbitrary and founded on assumptions clearly rooted in mid- to late-19th century religious or pseudo-religious, even occult, beliefs and practices (see Cavenaugh 2011; Waille 2012). A gesture pointing to the heart, for instance, as the spiritual centre of the body also had a spiritual connotation or meaning, a gesture pointing to the head was regarded as rational, whereas a gesture in any form connected to the lower body was, as one might expect, related to carnal and more profane aspects of human life. Shawn described the division of the human body according to Delsarte as follows: "Head: Concentric, mental, intellectual zone / Torso: Normal emotional, moral, spiritual zone / Limbs: Excentric, vital, physical zone" (Shawn 1963, 32). He then explained how far the origin of a gesture corresponded to its attributed character:

\begin{abstract}
For example, a movement originating in the upper torso would start with a strong influence of the emotional, affection, moral or spiritual—but if, proceeding through the arm, it finished lower than the hips, it would take on a more physical, sensuous character; if it ended within the realm of space opposite the upper torso, it would be pure and strong as to its moral-emotional-spiritual quality (i.e. pure affection); if it ended in the strata of space surrounding the head, it would take on a mental, directive quality; and if it ended above the head, would indicate a quality of ecstasy, a degree of emotion more than normal or natural; if directed front, a vital and mental quality, if sideways (outward) a stronger emotional indication, and if behind the body, out of the line of sight, a negative indication of rejection, fear. (Shawn 1963, 33)
\end{abstract}

Here, Shawn's shift from conceptualizing gestures emotionally (as pathos formulae) to a deliberate usage of ethos formulae becomes remarkably clear: Rather than surrendering the body to experiences of overwhelming, almost uncontrollable affectivity-like ecstasy, grief or fearexpressed in poses and gestures that stand in continuity with history or art, Shawn seems to opt for a far more controlled and reflective usage of gestures. He is obviously not primarily interested in the idea of a spontaneous, uncontrollable expression of emotions, but in indicating content or quality-be it moral, emotional or spiritual-through movement. Shawn thus uses gestures or ethos formulae in a rhetorical way: Rather than expressing emotions on stage, he seeks their communication to the audience by stimulating affective reactions in the individual audience members.

This might be related back to Aristotelian rhetoric, where orators-to which we might add, performers and dancers-don't necessarily act out emotions on stage, but rather evoke effects in the audience to influence and spurn them in their decisions. According to Aristotle's Rhetoric (Arist. 
$R h .1356 a)$, one of the three artistic proofs or modes of persuasion to achieve these effects is $\tilde{n} \theta$ oc (êthos) which refers to the integrity and character of the orator, but is also related to $\varepsilon$ हैo (éthos) meaning custom and convention. The other two modes of persuasion are $\lambda$ óyo (lógos), the logical

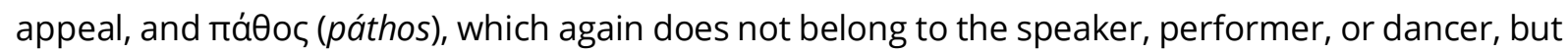
to the audience members, who react to the action onstage with a deliberately evoked affectivity (Knape 2010, 25). In a further development of this rhetorical system, Quintilian characterizes ethos as the milder and pathos as the stronger aspect and attributes to the first an appeasing effect while the latter is related to emotional turmoil (Inst. orat. VI, 1, 30).

Shawn's special understanding of Delsartism and his peculiar recourse to the codification of gestures, stands in the tradition of Aristotle's and Quintilian's rhetorical differentiation between ethos and pathos. Although his movement formulae certainly included gestures stirring pathos in the audience, the entire word field of ethos, with its meaning of custom, convention, and personal integrity, best reflects his own usage of movement formulae. The question remains, however, whether there is any particular ethical or moral dimension in Shawn's version of Delsartism and whether these are differentiated, as in Agamben's account? Shawn uses the term "ethical" only once in his study on Delsarte and not in clear distinction from morality. Referring to Alfred Giraudet's extensive introduction into the Delsarte-system (Giraudet 1885) Shawn writes:

\begin{abstract}
$[T]$ here is one gesture frequently abused by actors - the elongating of the index finger with the other fingers closed against the band. The expression of this position of the hand draws its meaning more from the point of departure of the whole gesture than from the position itself of hand and fingers. If the action starts naturally from the back of the head, it takes on a coloring of violence or menace; if the movement starts with the hand at or near the opposite shoulder, it shows a more controlled menace or intellectual force dominating the situation; and if the normal rotation of forearm and wrist starts with the band near the top of the head, there is a more moral or ethical and elevated character to the gesture. The first of these would threaten physical violence, the second would convey an intellectual threat, and the third, a moral admonition. (Shawn 1963, 111)
\end{abstract}

In arguing that "there is a more moral or ethical and elevated character" to a single gesture and in realising this attitude in his religiously themed choreographic work, Shawn distances himself from any critical investigation into the boundaries of movement codification. He rather approaches the ethics of gesture in an utterly nomistic way, almost completely contrarily to how Agamben conceptualizes ethics several decades later. In bringing ethical so close to moral, even using both terms interchangeably, and relating them to particular movements without keeping the arbitrariness of this relation in mind, Shawn best exemplifies those attempts to constitute ethics that Agamben so vigorously opposes. He reduces ethics to establishing and observing a nexus of highly nomistic movement codifications and, undermining the sheer potentiality of dancing, he realizes in Agamben's words "the destiny of morality [...], to regard potentiality itself, which is the most proper mode of human existence, as a fault that must always be repressed" (Agamben 1993, 44). Furthermore-and with regard to dancing-shifting ethos formula towards morality partly exempts the individuality of the one who embodies an encoded gesture in dance and also of those 
who perceive this movement. What is actually part of the concept of ethos formula, the triggering of individual decisions in accordance to ethical principles like justice, proportionality, and reciprocity, isn't totally suspended, but it is endangered. The essentialist understanding of movement codification that Shawn inherits from Delsarte, here culminates in a crucial ambiguity between the potentiality of dancing on the one hand and its unavoidable dependence on heteronomy on the other.

Shawn's strikingly hybrid usage of ethos formulae from the $19^{\text {th }}$ century Catholic theorist François Delsarte and his parallel practice of quoting liturgical gestures from Protestant, more specifically Methodist, services, pursues the ambiguity and uncanniness of modernity itself. For Shawn, like many other protagonists of modernist dance, argues on the one hand for freeing the body from the boundaries of classical ballet in the name of individual expression, and on the other hand for an instrumentalized body that still clings to principles of taxonomy and normativity. Furthermore, his belief in the essentialist character of ethos formulae and his conviction that gestures encode a universally valid form of communication goes together with his general view of dancing as a means of religious expression. For him, ethos formulae and liturgical gestures coincide since they both rely on assumptions of putatively universal significance that his own work hopes to exemplify. It is here, in Shawn's characteristically modernist delusion of grandeur, that ethics and aesthetics do indeed converge.

\section{Works Cited}

Agamben, Giorgio. 1993. The Coming Community. Translated by Michael Hardt. Minneapolis: University of Minnesota University Press.

. 2016. The Use of Bodies: Homo Sacer IV, 2. Translated by Adam Kotsko. Stanford: Stanford University Press.

Andresen, Carl. 1961. "Altchristliche Kritik am Tanz - ein Ausschnitt aus dem Kampf der Alten Kirche gegen heidnische Sitten." Zeitschrift für Kirchengeschichte 72: 217-62.

Brandstetter, Gabriele. 2013. Tanz-Lektüren: Körperbilder und Raumfiguren der Avantgarde. 2nd enl. ed. Freiburg i.Br: Rombach.

. 2015. Poetics of Dance: Body, Image, and Space in the Historical Avant-gardes. Translated by Elena Polzer and Mark Franko, Oxford: Oxford University Press.

Burt, Ramsay. 1995. The Male Dancer. Bodies, Spectacle, Sexualities. London: Routledge.

Cavenaugh, Greg. 2011. "Corresponding with Delsarte: Occult and Ontological Dimensions of Nineteenth-century Elocutionary Performance." Text and Performance Quarterly 31 (2): 130-48.

https://doi.org/10.1080/10462937.2010.551137

Desmond, Jane. 2001. "Dancing Out the Difference: Cultural Imperialism and Ruth St. Denis Radha of 1906." In Moving History/Dancing Cultures: A Dance History Reader, edited by Ann Dils and Ann Cooper Albright, 25670. Middletown: Wesleyan University Press.

Duncan, Isadora. 1903. Der Tanz der ZukunftThe Dance of the Future. Eine Vorlesung. Translated by Karl Federn. Leipzig: Diederichs.

Foster, Susan Leigh. 2001. "Closets Full of Dances: Masculinity and Sexuality in American Modern Dance." In Dancing Desires: Choreographing Sexualities on and off the Stage, edited by Jane C. Desmond, 147-208. Madison: University of Wisconsin Press. 
Gil, José. 2006. "Paradoxical Body." Translated by André Lepecki. TDR 50 (4): 21-35. https://doi.org/10.1162/dram.2006.50.4.21

Graham, Martha. 1991. Blood Memory. New York: Doubleday.

Giraudet, Alfred. 1895. Mimique: physionomie et gestes. Méthode pratique d'après le système de F. del Sarte pour servir à l'expression des sentiments. Paris: Librairies-imprimeries réunies.

Humphrey, Doris. 1995. An Artist First. Edited and completed by Selma Jeanne Cohen. Pennington: Princeton Book Co.

Jeschke, Claudia, and Gabi Vetterman. 1992. "François Delsarte." In Ausdruckstanz. Eine mitteleuropäische Bewegung der ersten Hälfte des 20. Jahrhunderts, edited by Gunhild Oberzaucher-Schüller, 15-24. Wilhelmshaven: Florian Noetzel.

Kabel, Thomas. 2002. Handbuch Liturgische Präsenz. Zur praktischen Inszenierung des Gottesdienstes. Vol. 1. Gütersloh: Gütersloher Verlagshaus.

Knape, Joachim. 2010. "Rhetorischer Pathosbegriff und literarische Pathosnarrative." In Pathos. Zur Geschichte einer problematischen Kategorie, edited by Cornelia Zumbusch, 25-44. Berlin: Akademie Verlag.

LaMothe, Kimerer L. 1998. "Passionate Madonna: The Christian Turn of American Dancer Ruth St. Denis." Journal of the American Academy of Religion 66 (4): 747-69. https://doi.org/10.1093/jaarel/66.4.747

_-_. 2006. Nietzsche's Dancers. Isadora Duncan, Martha Graham, and the Revaluation of Christian Values. Basingstoke: Palgrave Macmillan.

Legendre, Pierre. 1978. La passion d'être un autre: Étude pour la danse. Paris: Éditions du Seuil.

Lepecki, André. 2004. "Inscribing Dance." In Of the Presence of the Body. Essays on Dance and Performance Theory, edited by André Lepecki, 124-139. Middletown: Wesleyan University Press.

Liska, Vivian. 2008. Giorgio Agambens leerer Messianismus. Hannah Arendt. Walter Benjamin. Franz Kafka. Wien: Schlebrügge.

Manor, Giora, ed. 1986. Agadati: The Pioneer of Modern Dance in Israel. Tel Aviv: Sifriat Poalim/The Dance Library of Israel.

Manor, Giora, ed. 1988. Gertrud Kraus. Tel Aviv: Sifriat Poalim/The Dance Library of Israel.

Manning, Erin. 2009. Relationscapes: Movement, Art, Philosophy. Cambridge, MA: MIT Press.

Manning, Susan. 2014. Modern Dance, Negro Dance: Race in Motion. Minneapolis: University of Minnesota Press.

Miller, James L. 1986. Measures of Wisdom. The Cosmic Dance in Classical and Christian Antiquity. Toronto: University of Toronto Press.

Nietzsche, Friedrich. 2006. Thus Spoke Zarathustra. A Book for All and None. Translated by Adrian Del Caro. Cambridge: Cambridge University Press.

Preston, Carrie J. 2011. Modernism's Mythic Pose: Gender, Genre, Solo Performance. Oxford: Oxford University Press.

Ruyter, Nancy Lee Chalfa. 1999. The Cultivation of Body and Mind in Nineteenth-Century American Delsartism. Westport: Greenwood Press.

Schwan, Alexander. 2009. "Expression, Ekstase, Spiritualität: Paul Tillichs Theologie der Kunst und Mary Wigmans Absoluter Tanz." In Tanz, Bewegung \& Spiritualität, edited by Dagmar Ellen Fischer and Thom Hecht. 21426. Jahrbuch Tanzforschung 19. Leipzig: Henschel.

____. 2011. "Tanz, Wahnsinn und Gesetz. Eine kritische relecture von Pierre Legendre und Daniel Sibony." In Tanz \& WahnSinn/Dance \& ChoreoMania, edited by Johannes Birringer and Josephine Fenger. Jahrbuch Tanzforschung 21: 111-19. Leipzig: Henschel.

Scolieri, Paul A. 2016. "'An Interesting Experiment in Eugenics:' Ted Shawn, American Dance, and the Discourse of Sex, Race, and Ethnicity." In The Oxford Handbook of Dance and Ethnicity, edited by Anthony Shay and Barbara Sellers-Young, 187-209. Oxford: Oxford University Press. 
Shawn, Ted. 1926. The American Ballet. New York: Henry Holt \& Co.

1929. Gods Who Dance. New York: Dutton \& Co.

1963. Every Little Movement: A Book About François Delsarte, The Man and His Philosophy, His Science of Applied Aesthetics, The Application of This Science to the Art of the Dance, The Influence of Delsarte on American Dance. Rev. ed. New York: Dance Horizons.

___. 1974. Dance We Must. New York: Haskell.

1979. One Thousand and One Night Stands. New York: Da Capo Press.

Sibony, Daniel. 1995. Le corps et sa danse. Paris: Éditions du Seuil.

Siegmund, Gerald. 2012. "Negotiating Choreography, Letter, and Law in William Forsythe." In New German Dance Studies, edited by Susan Manning and Lucia Ruprecht, 200-16. Urbana: University of Illinois Press.

Taubes, Jacob. 1993. Die Politische Theologie des Paulus. Vorträge gehalten an der Forschungsstätte der evangelischen Studiengemeinschaft in Heidelberg, 23.-27. Februar 1987. Nach Tonbandaufzeichnungen redigierte Fassung von Aleida Assmann. Edited by Aleida Assmann and Jan Assmann. Munich: Wilhelm Fink.

Terry, Walter. 1976. Ted Shawn: Father of American Dance. New York: The Dial Press.

Wagner, Ann. 1997. Adversaries of Dance: From the Puritans to the Present. Urbana: University of Illinois Press.

Waille, Franck. 2012. "Les deux sources des enseignements de Delsarte: observations et métaphysique. De la multitude des signes à leur organisation systématique." In Kodikas, Code - Ars Semeiotica 35 (3/4), edited by Mathias Spohr: 213-38.

Warburg, Aby. 2010. "Dürer und die italienische Antike (1905)." In Werke in einem Band, edited by Martin Treml, Sigrid Weigel, and Perdita Ludwig, 176-86. Berlin: Suhrkamp.

Wedemeyer-Kolwe, Bernd. 2012. "François Delsarte und die deutsche Körperkulturbewegung." In Kodikas, Code Ars Semeiotica 35 (3/4), edited by Mathias Spohr: 314-18.

Wenger, Tisa J. 2006. 'The Practice of Dance for the Future of Christianity: 'Eurythmic Worship' in New York's Roaring Twenties." In Practicing Protestants: Histories of Christian Life in America, 1630-1965, edited by Laurie F. Maffly-Kipp, Leigh E. Schmidt, and Mark Valeri, 222-249. Baltimore: John Hopkins Press.

Wittgenstein, Ludwig. 1922. Tractatus Logico-Philosophicus. Translated by Frank P. Ramsey and Charles Kay Ogden. London: Routledge.

Zander, Helmut. 2001. "Körper Religion: Ausdruckstanz um 1900: Loïe Fuller, Isadora Duncan, Ruth St. Denis." In Protestantismus und Ästhetik: Religionskulturelle Transformationen am Beginn des 20. Jahrhunderts, edited by Volker Drehsen, Wilhelm Gräb, and Dietrich Korsch, 197-232. Gütersloh: Kaiser.

\section{Biography}

Alexander Schwan is a Postdoctoral Research Associate at the Institute of Theater Studies at Freie Universität Berlin. Prior to this, he studied Protestant theology, Jewish studies and philosophy in Heidelberg, Jerusalem, and Berlin, as well as theater directing at the Academy of Performing Arts, Frankfurt/Main. His dissertation, Correlations between Dancing and Writing in the Work of Trisha Brown, Jan Fabre, and William Forsythe, was awarded the 2016 Tiburtius Award. In his current book project, Alexander researches theological implications in the works of modernist choreographers such as Ruth St. Denis, Mary Wigman, and Martha Graham, as well as the reception of German and Austrian expressionist dance (Ausdruckstanz) in British Mandate Palestine. In the fall term of 2017, Alexander will be a visiting scholar at Harvard University.

\section{(c) 2017 Alexander Schwan}

Except where otherwise noted, this work is licensed under a Creative Commons Attribution-

NonCommercial-ShareAlike 4.0 International License. 